\title{
Apolipoprotein E in Synaptic Plasticity and Alzheimer's Disease: Potential Cellular and Molecular Mechanisms
}

\author{
Jaekwang Kim ${ }^{1}$, Hyejin Yoon ${ }^{1,2}$, Jacob Basak ${ }^{3}$, and Jungsu Kim ${ }^{1,2, *}$
}

\begin{abstract}
Alzheimer's disease (AD) is clinically characterized with progressive memory loss and cognitive decline. Synaptic dysfunction is an early pathological feature that occurs prior to neurodegeneration and memory dysfunction. Mounting evidence suggests that aggregation of amyloid- $\beta$ $(A \beta)$ and hyperphosphorylated tau leads to synaptic deficits and neurodegeneration, thereby to memory loss. Among the established genetic risk factors for $A D$, the $\varepsilon 4$ allele of apolipoprotein E (APOE) is the strongest genetic risk factor. We and others previously demonstrated that apoE regulates $A \beta$ aggregation and clearance in an isoform-dependent manner. While the effect of apoE on $A \beta$ may explain how apoE isoforms differentially affect $A D$ pathogenesis, there are also other underexplored pathogenic mechanisms. They include differential effects of apoE on cerebral energy metabolism, neuroinflammation, neurovascular function, neurogenesis, and synaptic plasticity. ApoE is a major carrier of cholesterols that are required for neuronal activity and injury repair in the brain. Although there are a few conflicting findings and the underlying mechanism is still unclear, several lines of studies demonstrated that apoE4 leads to synaptic deficits and impairment in long-term potentiation, memory and cognition. In this review, we summarize current understanding of apoE function in the brain, with a particular emphasis on its role in synaptic plasticity and the underlying cellular and molecular mechanisms, involving low-density lipoprotein receptor-related protein 1 (LRP1), syndecan, and LRP8IApoER2.
\end{abstract}

\section{ALZHEIMER'S DISEASE}

Alzheimer's disease (AD) is the most common cause of de-

${ }^{1}$ Department of Neuroscience, Mayo Clinic College of Medicine, Jacksonville, FL 32224, USA, ${ }^{2}$ Neurobiology of Disease Graduate Program, Mayo Graduate School, Jacksonville, FL 32224, USA, ${ }^{3}$ Department of Neurology, Hope Center for Neurological Disorders, Washington University School of Medicine, St. Louis, MO 63110, USA

${ }^{*}$ Correspondence: kim.jungsu@mayo.edu

Received 11 September, 2014; accepted 14 September, 2014; published online 30 October, 2014

Keywords: Alzheimer's disease, ApoER2, Apolipoprotein E, HSPG, LRP1, synaptic plasticity mentia in the elderly. Two neuropathological hallmarks of $A D$ are extracellular $A \beta$ aggregation and intraneuronal neurofibrillary tangles, mainly composed of hyperphosphorylated tau (Golde et al., 2010). Although the exact pathogenic mechanism of $A D$ is still debated, accumulating evidence supports that abnormal aggregation of $A \beta$ in the brain is an early event that triggers pathogenic cascades. $A \beta$ species, including the most abundant $A \beta 40$ and more toxic $A \beta 42$, are produced by two sequential proteolytic cleavages of amyloid precursor protein (APP) by $\beta$ and $y$-secretases (Kim et al., 2007; McGowan et al., 2005). Genetic mutations responsible for dominant early-onset familial $A D$ are found in APP and presenilin 1 and 2, essential components of $y$-secretase complex. In general, such mutations increase $A \beta$ production or increase $A \beta 42$ to $A \beta 40$ ratio. However, only less than $1-3 \%$ of $A D$ cases account for familial AD carrying these genetic mutations. Most cases of $A D$ are late-onset and most individuals with late-onset sporadic $A D$ (LOAD) do not have mutations that enhance $A \beta$ production. Therefore, defective $A \beta$ clearance may underlie the increase of $A \beta$ level and $A D$ pathogenesis. Although non-genetic environmental factors, such as age and low education, affect the risk of sporadic $A D$, the strongest genetic risk factor of $L O A D$ is the $A P O E$ $\varepsilon 4$ allele (Kim et al., 2009a). Mounting evidence suggests that the influence of apoE on $A D$ may be mainly via its effect on clearance and aggregation of $A \beta$, even though cellular mechanisms for both processes are still unclear.

\section{SYNAPTIC DYSFUNCTION IN ALZHEIMER'S DISEASE}

Major clinical characteristic of $A D$ patients is progressive decline in memory with an initial impairment of short-term declarative memory, followed by losses of multiple cognitive functions. Given the fact that synaptic dysfunction is directly related to memory loss, it is important to realize that synaptic loss is an early pathological feature of AD (Selkoe, 2002). In various efforts to find semiquantitative correlations between the progressive cognitive impairment and pathological alterations, such as severity of plaque or neurofibrillary tangles, the best statistical correlation was found between the loss of synaptic density and the degree of cognitive impairment in AD (Terry et al., 1991). Several studies support that loss of synaptic number and density precedes the demise of the neuron (Walsh and Selkoe, 2004). An increasing line of evidence suggests that accumulation of soluble $A \beta$ may be a key factor of synaptic loss and cognitive impairment (Haass and Selkoe, 2007). In addition, synaptic deficit tends to correlate well with soluble $A \beta$ level in various 
APP transgenic mouse models. Therefore, it appears that lowering soluble $A \beta$ level in the brain is a promising therapeutic strategy to restore synaptic function and prevent cognitive decline.

\section{APOE IN ALZHEIMER'S DISEASE}

ApoE4, found in $65-80 \%$ of cases of sporadic and familial Alzheimer's disease, increases the occurrence of $A D$ by $\sim 12$ fold in two $\varepsilon 4$ allele carriers, compared with those with no $\varepsilon 4$ allele (Farrer et al., 1997). Rare apoE2 allele has a protective effect against LOAD compared to other alleles (Corder et al., 1993). Numerous studies demonstrated the differential effect of apoE isoforms on the clearance and aggregation of $A \beta$ (Kim et al., 2009a). Although the mechanisms underlying the $A \beta$-mediated pathological effects of apoE are still not clear, mounting evidence suggests that the physical and genetic interactions between apoE and $A \beta$ may have critical roles in $A D$ pathogenesis. Interestingly, apoE colocalizes with amyloid plaques (Namba et al., 1991). ApoE gene deletion in APP transgenic mice leads to dramatically decreased amyloid plaques without affecting $A \beta$ production (Bales et al., 1997). ATP-binding cassette transporter A1 (ABCA1) overexpression in APP transgenic mice also showed a similar phenotype (Wahrle et al., 2008). ABCA1mediated lipidation of apoE may play a key role in facilitating $A \beta$ degradation by $A \beta$-degrading enzymes (Jiang et al., 2008). Furthermore, overexpression of apoE receptor, low-density lipoprotein receptor (LDLR), dramatically decreased $A \beta$ deposition in vivo (Kim et al., 2009b). These genetic approaches provide strong support for apoE-targeting therapeutic strategy. Indeed, several groups tested whether targeting apoE with a more practical approach would have functional effects on $A \beta$ and other pathological process in vivo. For example, an $A \beta 12-$ 28 synthetic peptide, which contains the apoE-binding site, reduced cerebral $A \beta$ accumulation in animal models of $A \beta$ amyloidosis (Kuszczyk et al., 2013; Pankiewicz et al., 2014; Sadowski et al., 2004; 2006). In addition, apoE mimetic peptide affected APP trafficking and inhibited A $\beta$ production (Minami et al., 2010). Because apoE is tightly related to the regulation of $A \beta$ level and $A D$ pathogenesis, several modes of apoE modulation, such as altering its expression level or status of its lipidation, are pursed as promising therapeutic targets (Bien-Ly et al., 2012; Castellano et al., 2011; Cramer et al., 2012; Kim et al., 2009b; 2011; 2012a; 2012b; Liao et al., 2014; Wahrle et al., 2008;).

\section{GENERAL FUNCTION AND STRUCTURE OF APOE}

ApoE transports cholesterol and other lipids in the plasma and brain through cell surface apoE binding receptors (LaneDonovan et al., 2014). In brain, apoE is the predominant apolipoprotein of high-density lipoprotein (HDL)-like lipoprotein particle, whereas ApoA-1 is major form of plasma HDL. Following the receptor-mediated endocytosis of lipoprotein particles, apoE is either degraded or recycled back to cell surface. ApoE is highly expressed in liver and brain. Within brain, apoE is mainly synthesized by astrocytes and to a limited extent by microglia. Cholesterol is a major component of neuronal and glial membranes and myelin sheath and is produced by glia and neuron. However, mature neurons appear not to produce sufficient cholesterol for membrane synthesis and repair. Therefore, lipid transports may be critical to maintaining neuronal activity (Dietschy and Turley, 2004).

Human ApoE, composed of 299 amino acids, has two separate $\mathrm{N}$-terminal and $\mathrm{C}$-terminal domains joined by a flexible hinge region. The $\mathrm{N}$-terminal domain and $\mathrm{C}$-terminal domain have the receptor-binding and the lipid-binding region, respectively. There are three major isoforms (apoE2, apoE3, and apoE4) in humans, whereas mice express only one type of apoE protein (Kim et al., 2009a). ApoE3 is the most predominant isoform, accounting almost $80 \%$ of alleles in general population, while two other forms are minor. Isoforms differ at one or two positions in their primary sequence. ApoE3 has cysteine112 and arginine-158, whereas apoE4 and apoE2 have arginine and cysteine, respectively at both positions. The differences of one or two amino acids among isoforms significantly alter the apoE's folding structure and change its ability to bind lipid and receptor (Mahley and Huang, 2012). ApoE3 and apoE4 have a much higher affinity to LDLR, compared with apoE2. So far, more than ten receptors of LDLR family have been identified and most members of the LDLR family bind to apoE. In addition to the lipoprotein endocytic function, some apoE receptors also mediate cellular signaling by binding to other extracellular ligands and intracellular adaptors. For example, reelin-mediated signaling through LRP8/APOER2 and very-low-density-lipoprotein receptor is crucial to synaptic plasticity (Lane-Donovan et al., 2014).

\section{ROLE OF APOE IN SYNAPTIC PLASTICITY AND COGNITION}

Differential effects of ApoE isoforms on neurite outgrowth in vitro

Although the differential effects of apoE isoforms on $A \beta$ aggregation and clearance have been extensively studied (Kim et al., 2009a), A $\beta$-independent pathogenic mechanisms have not been thoroughly investigated. In addition to their effects on $A \beta$ clearance, apoE isoforms affect synaptic plasticity in an isoform-dependent manner. Neuronal injuries are known to induce apoE expression and such increase in apoE level may help to repair the nervous system by delivering cholesterols and lipids to neurons (Mahley and Huang, 2012). Among the processes associated with synaptic plasticity, the effects of apoE isoforms on a neurite outgrowth have been widely investigated. Neurite is defined as any protruding projection from the neuronal cell body, either axon or dendrite. Most studies have demonstrated that apoE3 isoform promotes neurite outgrowth in primary embryonic and adult cortical neurons, as well as neuronal cell lines (Nathan et al., 1994; 2002; Sun et al., 1998). Furthermore, apoE3 was shown to augment neuronal sprouting in a developing organotypic hippocampal slice system (Teter et al., 1999). However, the effect of apoE4 on neurite outgrowth phenotype was not consistent between studies. While some studies reported that apoE4 had detrimental effects on neurite outgrowth (Teter et al., 2002), others found no effects (DeMattos et al., 1998) or even stimulating effects (Puttfarcken et al., 1997).

ApoE isoform dependent synaptic phenotypes in mouse models

Findings from in vitro cell culture studies appear to be consistent with most results obtained with apoE mouse models (Table 1). For example, compensatory sprouting after entorhinal cortex lesion was impaired in transgenic mice expressing apoE4 under the control of human promoter, compared with apoE3 transgenic mice (White et al., 2001). Such synaptic structural differences observed in neurons might explain findings from cognitive performance tests with apoE isoform mice. In transgenic mouse models with neuronal apoE over-expression, apoE4 mice, primarily females, had impair- 
Table1. Summary of $A P O E$ transgenic and knock-in mouse models

\begin{tabular}{|c|c|c|c|c|c|}
\hline Transgene & Promoter & Phenotypes & $\begin{array}{c}\text { Age } \\
\text { (months) }\end{array}$ & Note & REF \\
\hline Human apoE3,E4 & Human apoE & $\begin{array}{c}\text { Impaired neuronal plasticity in apoE4 } \\
\text { TG compared to apoE3 TG after } \\
\text { entorhinal cortex lesion }\end{array}$ & 3 & $\begin{array}{c}\text { Measured inner } \\
\text { molecular layer and } \\
\text { immunoreactivity of } \\
\text { synaptophysin and } \\
\text { GAP-43 }\end{array}$ & $\begin{array}{l}\text { (White et al., } \\
\text { 2001) }\end{array}$ \\
\hline Human apoE3,E4 & NSE & $\begin{array}{l}\text { Impairment of WM task and vertical } \\
\text { exploratory behavior in apoE4 TG } \\
\text { compared to WT and apoE3 TG }\end{array}$ & $5-6$ & $\begin{array}{l}\text { More susceptible in } \\
\text { female and aged mice }\end{array}$ & $\begin{array}{c}\text { (Raber et al., } \\
\text { 1998) }\end{array}$ \\
\hline $\begin{array}{l}\text { Human apoE3,E4 } \\
\text { TG crossed with } \\
\text { human APP }\end{array}$ & NSE & $\begin{array}{c}\text { ApoE3 TG is less susceptible to the } \\
\text { detrimental effect of APP/A } \beta \text { on WM } \\
\text { performance than apoE4 TG }\end{array}$ & 6 & $\begin{array}{l}\text { More susceptible in fe- } \\
\text { male and aged mice }\end{array}$ & $\begin{array}{l}\text { (Raber et al., } \\
\text { 2000) }\end{array}$ \\
\hline $\begin{array}{l}\text { Human apoE3,E4 } \\
\text { and apoE KO }\end{array}$ & GFAP & $\begin{array}{c}\text { ApoE3,E4 TG and KO were } \\
\text { emotionally more reactive than WT. } \\
\text { ApoE4 TG showed impaired } \\
\text { performance in RAM }\end{array}$ & $5-14$ & $\begin{array}{l}\text { Performed other multiple } \\
\text { cognitive tests }\end{array}$ & $\begin{array}{l}\text { (Hartman } \\
\text { et al., 2001) }\end{array}$ \\
\hline $\begin{array}{l}\text { Human } \\
\text { apoE2,E3,E4 } \\
\text { and apoE KO }\end{array}$ & Human apoE & $\begin{array}{l}\text { ApoE4 TG had synaptic loss } \\
\text { accompanied by an increase in } \\
\text { synapse size during aging, compared } \\
\text { to the other genotypes }\end{array}$ & $6-24$ & $\begin{array}{l}\text { Measured synapse per } \\
\text { neuron ratio and synapse } \\
\text { size in dentate gyrus }\end{array}$ & $\begin{array}{l}\text { (Cambon } \\
\text { et al., 2000) }\end{array}$ \\
\hline apoE KO & $\mathrm{N} / \mathrm{A}$ & $\begin{array}{l}\text { Infusion of apoE3 and E4 into apoE } \\
\text { KO mice improved WM performance, } \\
\text { compared to apoE KO }\end{array}$ & 8 & $\begin{array}{l}\text { Infused recombinant } \\
\text { apoE3 and E4 }\end{array}$ & $\begin{array}{l}\text { (Masliah } \\
\text { et al., 1997) }\end{array}$ \\
\hline $\begin{array}{l}\text { Human apoE3,E4 } \\
\text { and apoE KO }\end{array}$ & Human apoE & $\begin{array}{c}\text { ApoE3 expression preserved } \\
\text { neuronal integrity in aged mice } \\
\text { better than apoE4 expression or } \\
\text { apoE KO did }\end{array}$ & 12 & $\begin{array}{l}\text { Performed WM and } \\
\text { measured } \\
\text { immunoreactivity of } \\
\text { synaptophysin and } \\
\text { GAP-43 }\end{array}$ & $\begin{array}{l}\text { (Veinbergs } \\
\text { et al., 1999) }\end{array}$ \\
\hline $\begin{array}{l}\text { Human apoE2 TG } \\
\text { crossed with } \\
\text { Tg2576 or } \\
\text { PDAPP }\end{array}$ & $\begin{array}{l}\text { Human } \\
\text { transferrin }\end{array}$ & $\begin{array}{l}\text { Spine density loss was ameliorated by } \\
\text { apoE2 overexpression both in Tg2576 } \\
\text { and PDAPP }\end{array}$ & $\begin{array}{c}2,5,8 \\
\text { (PDAPP) } \\
4.5,11 \\
(\operatorname{Tg} 2576)\end{array}$ & & $\begin{array}{l}\text { (Lanz et al., } \\
\text { 2003) }\end{array}$ \\
\hline Human apoE3,E4 & NSE & $\begin{array}{l}\text { ApoE3, but not apoE4, expression } \\
\text { protected against neuronal damage } \\
\text { and the age-dependent } \\
\text { neurodegeneration compared to apoE } \\
\text { KO }\end{array}$ & $3-4,7-9$ & & $\begin{array}{l}\text { (Buttini et al., } \\
\text { 1999) }\end{array}$ \\
\hline $\begin{array}{l}\text { Human } \\
\text { apoE2,E3,E4 KI } \\
\text { crossed with } \\
\text { R1.40 APP }\end{array}$ & endogenous & $\begin{array}{c}\text { All human apoE genotypes had } \\
\text { increased brain cholesterol and } \\
\text { A } \beta \text { levels }\end{array}$ & 28 days & $\begin{array}{l}\text { Differential effect of apoE } \\
\text { on cholesterol metabo- } \\
\text { lism and A } \beta \text { levels in } \\
\text { periphery relative to CNS }\end{array}$ & $\begin{array}{l}\text { (Mann } \\
\text { et al., 2004) }\end{array}$ \\
\hline $\begin{array}{l}\text { Human apoE3,E4 } \\
\text { KI and Arg-61 } \\
\text { apoE }\end{array}$ & endogenous & $\begin{array}{c}\text { The levels of apoE4 and Arg- } 61 \text { apoE } \\
\text { in brain were lower than the that of } \\
\text { apoE3 and WT, respectively }\end{array}$ & $5,12,24$ & $\begin{array}{l}\text { Domain interaction was } \\
\text { introduced in Arg- } 61 \\
\text { apoE mice by gene } \\
\text { targeting }\end{array}$ & $\begin{array}{l}\text { (Ramaswamy } \\
\text { et al., 2005) }\end{array}$ \\
\hline $\begin{array}{l}\text { Human apoE3/3, } \\
\text { E4/4, E3/0 KI }\end{array}$ & endogenous & $\begin{array}{c}\text { Inflammatory response; } \\
\text { apoE4/4 > apoE3/0 > apoE3/3 }\end{array}$ & & $\begin{array}{l}\text { Inhibition of inflammation } \\
\text { depends upon the dose } \\
\text { of available apoE3 } \\
\text { protein }\end{array}$ & $\begin{array}{l}\text { (Vitek et al., } \\
\text { 2007) }\end{array}$ \\
\hline $\begin{array}{l}\text { Human } \\
\text { apoE2/2,E3/3,E } \\
4 / 4 \mathrm{KI}\end{array}$ & endogenous & $\begin{array}{l}\text { Genotype dependent apoE level; } \\
\text { apoE2/2 > apoE3/3 > apoE4/4 }\end{array}$ & $3-5$ & $\begin{array}{l}\text { Preferential degradation } \\
\text { of apoE4 in astrocyte } \\
\text { may lead to reduced } \\
\text { secretion and reduced } \\
\text { brain apoE4 level }\end{array}$ & $\begin{array}{l}\text { (Riddell et al., } \\
\text { 2008) }\end{array}$ \\
\hline $\begin{array}{l}\text { Human } \\
\text { apoE3/3,E4/4 } \\
\text { KI }\end{array}$ & endogenous & $\begin{array}{c}\text { Reduced excitatory synaptic } \\
\text { transmission and dentritic arborization } \\
\text { in the amygdala of apoE4 KI } \\
\text { compared to } \mathrm{E} 3 \mathrm{KI}\end{array}$ & 30 weeks & $\begin{array}{l}\text { No significant gliosis, } \\
\text { amyloid deposition or } \\
\text { neurofibrillary tangles in } \\
\text { apoE4 KI mice }\end{array}$ & $\begin{array}{l}\text { (Wang et al., } \\
\text { 2005) }\end{array}$ \\
\hline
\end{tabular}

(continued) 


\begin{tabular}{|c|c|c|c|c|c|}
\hline Transgene & Promoter & Phenotypes & $\begin{array}{c}\text { Age } \\
\text { (months) }\end{array}$ & Note & REF \\
\hline $\begin{array}{l}\text { Human apoE2,E3, } \\
\text { E4 KI and apoE } \\
\text { KO }\end{array}$ & endogenous & $\begin{array}{c}\text { LTP magnitude; } \\
\text { WT and apoE3 > apoE KO and } \\
\text { apoE2 }>\text { apoE4 }\end{array}$ & $2-4$ & & $\begin{array}{l}\text { (Trommer } \\
\text { et al., 2004) }\end{array}$ \\
\hline $\begin{array}{l}\text { Human apoE3,E4 } \\
\qquad \mathrm{KI}\end{array}$ & endogenous & $\begin{array}{l}\text { Hippocampal LTP was enhanced at a } \\
\text { younger age in apoE } 4 \mathrm{KI} \text { but not } \\
\text { in apoE3 KI }\end{array}$ & $\begin{array}{c}8 \text { weeks, } \\
6-7\end{array}$ & $\begin{array}{c}\text { Showed age dependent } \\
\text { effect }\end{array}$ & $\begin{array}{l}\text { (Kitamura } \\
\text { et al., 2004) }\end{array}$ \\
\hline $\begin{array}{l}\text { Human apoE3,E4 } \\
\mathrm{KI} \text { and apoE } \\
\mathrm{KO}\end{array}$ & endogenous & $\begin{array}{l}\text { ApoE4 } \mathrm{KI} \text {, predominantly in female, } \\
\text { showed deficit in spatial memory } \\
\text { compared to apoE3 KI }\end{array}$ & $4-5$ & & $\begin{array}{l}\text { (Grootendorst } \\
\text { et al., 2005) }\end{array}$ \\
\hline $\begin{array}{l}\text { Human apoE3, E4 } \\
\mathrm{KI} \text { and apoE } \\
\mathrm{KO}\end{array}$ & endogenous & $\begin{array}{l}\text { ApoE4 } \mathrm{KI} \text { showed impaired } \\
\text { performance in WM and fear } \\
\text { conditioning task }\end{array}$ & $15-18$ & $\begin{array}{l}\text { Female apoE4 } \mathrm{KI} \text { was } \\
\text { more deteriorated }\end{array}$ & $\begin{array}{l}\text { (Bour et al., } \\
\text { 2008) }\end{array}$ \\
\hline $\begin{array}{l}\text { Human } \\
\text { apoE2,E3,E4 KI }\end{array}$ & endogenous & $\begin{array}{c}\text { ApoE4 KI showed reduced } \\
\text { cortical dendritic spine density and } \\
\text { complexity in cortex compared to } \\
\text { other KI mice }\end{array}$ & $\begin{array}{l}\text { 4weeks, } \\
3,12\end{array}$ & $\begin{array}{l}\text { Showed age dependent } \\
\text { effect }\end{array}$ & $\begin{array}{l}\text { (Dumanis } \\
\text { et al., 2009) }\end{array}$ \\
\hline $\begin{array}{l}\text { Human } \\
\text { apoE2,E3,E4 KI } \\
\text { and apoE KO }\end{array}$ & endogenous & $\begin{array}{l}\text { LTP was inhibited by oligomeric aß } \\
\text { 1-42 with susceptibility of; } \\
\text { apoE4 > apoE3 = apoE KO > apoE2 }\end{array}$ & $2-4$ & $\begin{array}{l}\text { apoE4: gain of negative } \\
\text { function } \\
\text { apoE2: loss of protective } \\
\text { function }\end{array}$ & $\begin{array}{l}\text { (Trommer } \\
\text { et al., 2005) }\end{array}$ \\
\hline $\begin{array}{l}\text { Human apoE3,E4 } \\
\qquad \mathrm{KI}\end{array}$ & endogenous & $\begin{array}{l}\text { ApoE4 KI exhibited deficits in RAM, } \\
\text { which was improved after exercise. }\end{array}$ & $10-12$ & & $\begin{array}{l}\text { (Nichol et al., } \\
\text { 2009) }\end{array}$ \\
\hline $\begin{array}{l}\text { Human apoE3,E4 } \\
\text { KI crossed with } \\
\text { human APP }\end{array}$ & endogenous & $\begin{array}{l}\text { apoE4 KI showed reduction in } \\
\text { locomotor activity and cognitive } \\
\text { impairment compared to apoE3 KI }\end{array}$ & $6-7$ & & $\begin{array}{l}\text { (Kornecook } \\
\text { et al., 2010) }\end{array}$ \\
\hline apoE KO & $\mathrm{N} / \mathrm{A}$ & $\begin{array}{c}\text { Impaired memory in apoE KO mice } \\
\text { Decreased cholinergic activity in } \\
\text { hippocampus and frontal cortex of } \\
\text { apoE KO }\end{array}$ & 6 & & $\begin{array}{l}\text { (Gordon } \\
\text { et al., 1995) }\end{array}$ \\
\hline $\begin{array}{l}\text { Human } \\
\text { apoE2,E3,E4 KI }\end{array}$ & $\begin{array}{l}\text { Endogenous } \\
\text { or GFAP }\end{array}$ & $\begin{array}{c}\text { Cognitive performance decreased } \\
\text { with age in all isoform mice. ApoE4 KI } \\
\text { had better cognitive performance and } \\
\text { higher anxiety than apoE2 and } \\
\text { apoE3 KI }\end{array}$ & $\begin{array}{l}6-8,10-13 \\
14-22\end{array}$ & $\begin{array}{l}\text { Used young, } \\
\text { middle-aged and } \\
\text { old females }\end{array}$ & $\begin{array}{l}\text { (Siegel et al., } \\
\text { 2012) }\end{array}$ \\
\hline
\end{tabular}

REF, reference; NSE, neuron-specific enolases; GFAP, glial fibrillary acidic protein; KO, knock-out; KI, knock-in; TG, transgenic mouse; WM, water maze test; RAM, radial arm maze test; LTP, long term potentiation

ments in learning a water maze test and in vertical exploratory activity, compared with apoE3 mice (Raber et al., 2000). Interestingly, there was no difference in soluble $A \beta$ levels between apoE3/APP and apoE4/APP transgenic mice, suggesting that the differential effect of apoE isoform on cognition may be due to its ability to modulate functional neuronal deficits triggered by $A \beta$ or APP. Using another transgenic mouse model where the apoE isoform is expressed in astrocytes, Hartman et al. also demonstrated that apoE4 mice were more severely impaired in working memory in a radial arm maze test (Hartman et al., 2001). Other previous studies also reported an association between the apoE4 and spine deficits in vivo (Basak and Kim, 2010; Dumanis et al., 2009; Ji et al., 2003; Wang et al., 2005).

Although most studies reported that apoE3 increased synaptic plasticity and had neuroprotective effects to a greater extent, relative to apoE4, the effects of apoE4 were not consistent between studies. Both negative effects and minor beneficial effects on neurites and synaptic functions have been associat- ed with apoE4 (Cambon et al., 2000; Masliah et al., 1997; Veinbergs et al., 1999). In one sense, such conflicting data from in vivo studies reflect the inconsistent results obtained from in vitro experiments (DeMattos et al., 1998; Puttfarcken et al., 1997; Teter et al., 2002). Unlike other two isoforms, apoE2 has not been studies extensively but consistent data appear to support its neuroprotective function (Hudry et al., 2013). In one study, dendritic spine loss in the hippocampus of young APP transgenic mice was ameliorated by apoE2 over-expression with a transferrin promoter, although an age-dependent reduction in spine density was not prevented by apoE2 expression (Lanz et al., 2003).

It has been generally assumed that matching apoE protein levels between isoform mice will circumvent any potential artifacts due to the difference in apoE expression levels. Indeed, since most apoE transgenic mice were generated with promoters from extraneous genes, such as neuron-specific enolase, glial fibrillary acidic protein, thymocyte differentiation antigen 1 , 
or platelet-derived growth factor, transgenic founder lines with equivalent apoE expression levels between isoforms were often selected for further experiments (Table 1). However, later studies strongly suggest that there are considerable differences in apoE protein levels between $A P O E$ isoform knock-in mice where apoE transcription is driven by an endogenous $A P O E$ promoter (Kim et al., 2009a). Given significant differences in apoE levels under normal physiological conditions, the relevance of findings from transgenic mice with equivalent apoE protein levels becomes less straightforward.

However, some phenotypes observed in apoE transgenic mouse models have been reproduced in apoE knock-in mouse models. For example, apoE4 knock-in mice showed significantly reduced excitatory synaptic transmission and dendritic arborization in the absence of noticeable neuropathological changes (Wang et al., 2005). Consistent with such synaptic deficits, long-term potentiation (LTP) was reduced in apoE4 knock-in mice, compared with apoE3 mice (Trommer et al., 2004), although another study showed young apoE4 mice had enhanced LTP (Kitamura et al., 2004). Differences in experimental conditions, such as high-frequency stimulation versus tetanic stimulation, might contribute to the apparently conflicting results. Surprisingly, LTP in apoE2 knock-in mice was significantly less than apoE3 mice and comparable with apoE4 mice (Trommer et al., 2004). Although it was hypothesized that the weaker binding affinity of apoE2 to apoE receptors may underlie the LTP reduction in apoE2 mice, further studies are needed to clarify the underlying mechanism. Nonetheless, subsequent studies demonstrate that apoE4 knock-in mice, particularly females, have deficits in spatial memory performance tests, compared to apoE3 mice (Bour et al., 2008; Grootendorst et al., 2005). As discussed here, apoE isoforms have differential effects on synaptic function in mouse models. However, whether these findings from mouse models are directly relevant to human $A D$ still remains unknown.

Apparently normal cognition in a human subject without functional APOE gene

Recently, one study provided a unique insight into a longstanding debate in the AD field (Mak et al., 2014). An apparently simple question of whether we should increase or decrease apoE levels for $A D$ therapy has been a controversial topic in the field (Osherovich, 2009). Some groups and pharmaceutical companies are trying to "increase" the levels of apoE, even apoE4, to boost apoE's ability to transport lipid and clear/degrade $A \beta$ levels, whereas others are developing strategies to "decrease" apoE levels or block apoE4's toxic effects. These entirely opposite approaches are based on completely different assumption of disease mechanism. Does apoE4 affect $A D$ risk by the gain of detrimental functions or the loss of protective functions? While apoE does have lipid transporter functions under normal physiological conditions, whether its physiological function is directly relevant to its role under pathological AD conditions is still unknown. One of the strongest arguments against the apoE reduction approach was the impairment of cholesterol and other lipid transport in the brain, leading to severe cognitive impairment. The study by Mak et al. (2014) provides one of the first answers to this critical question. The authors identified a patient with no detectable apoE level due to a frameshift mutation in APOE gene. As expected from apoE's role in lipid transport, this patient had high levels of cholesterol and triglycerides in plasma, leading to familial dysbetalipoproteinemia. However, he did not have any severe abnormality in his cognition and other neurological function. In addition, the levels of $A \beta 42$, total tau, and phospho-tau in his cerebrospinal fluid were normal. These findings suggest that therapeutics aiming to reduce apoE levels in the brain will unlikely cause adversary cognitive effect. While this study apparently provides support for apoE reduction approach, the results do not necessarily provide direct insight into the role of apoE in $A D$ pathogenesis. The elegant study by Mak et al., addressed the normal physiological function of apoE in the brain. Further follow-up study with this patient during his aging and the lipoprotein profiles from his cerebrospinal fluid will dramatically enhance our understanding of apoE in $A D$ pathogenesis.

\section{POTENTIAL CELLULAR AND MOLECULAR MECHANISMS}

\section{Regulation of neurite outgrowth by LRP1}

Membrane trafficking and cargo delivery along the actin and microtubule cytoskeleton are essential for dendritic and axonal outgrowth and guidance. Neurites are packed with actin, microtubule bundles, and microtubule-binding proteins, such as tau protein. Numerous studies demonstrated that apoE isoforms affect neurite outgrowth in an isoform-dependent manner. The stimulation of neurite outgrowth by apoE is, in part, mediated by LRP1 (Fagan et al., 1996; Holtzman et al., 1995; Narita et al., 1997; Nathan et al., 2002). Attenuation of apoE's effect on neurite outgrowth by anti-LRP1 antibody or receptor associated protein (RAP) provides strong evidence for the involvement of LRP1. In addition, Shi et al. (2009) demonstrated that activation of LRP1 by other ligands, such as tissue-type plasminogen activator (tPA) or $\alpha 2$-macroglobulin, activates Src family kinase and TrK receptor in neurons (Fig. 1B). Phosphorylation of Trk receptors was necessary for neurite outgrowth. However, it is unknown whether apoE can also activate the same signal transduction pathway triggered by other apoE receptor ligands. If the LRP1-mediated effect is the major mechanism, it is unclear how apoE isoforms would exert the differential effects on neurite sprouting, given the fact that LRP1 has little isoformspecific difference in its binding affinity to apoE3 and apoE4 (Kowal et al., 1990; Ruiz et al., 2005).

Regulation of neurite outgrowth by syndecan family member proteins

Other apoE receptors could also mediate apoE isoform-specific effect on neurite outgrowth by its differential biding affinity to each apoE isoform. For example, apoE is known to bind to heparan sulfate proteoglycan (HSPG) through its N-terminal domain (142-147 amino acid domain) (Libeu et al., 2001). HSPGs consist of a core protein and one or more covalently attached heparin sulfate polysaccharides. They are localized at the basal lamina and in the dendrites. HSPG can take up extracellular apoE-containing lipoproteins, independent of LDLR and LRP1. Higher intracellular levels of apoE3, compared to apoE4, in neurons are associated with isoform-specific effects of apoE on neurite outgrowth phenotype. Interestingly, this differential retention of apoE isoforms in neurons is mediated by HSPG (Ji et al., 1998).

Among many HSPGs, syndecan family member proteins appear to be promising candidates that might mediate apoEisoform dependent neurite outgrowth and dendritic spine maturation. The members of syndecan family are transmembrane HSPGs and their core proteins share a highly conserved cytoplasmic domain. Cytoplasmic domain interacts with actin filaments and tyrosine kinases of the Src family (Fig. 1A). For example, N-syndecan (syndecan-3) acts as a receptor for hepa- 
A

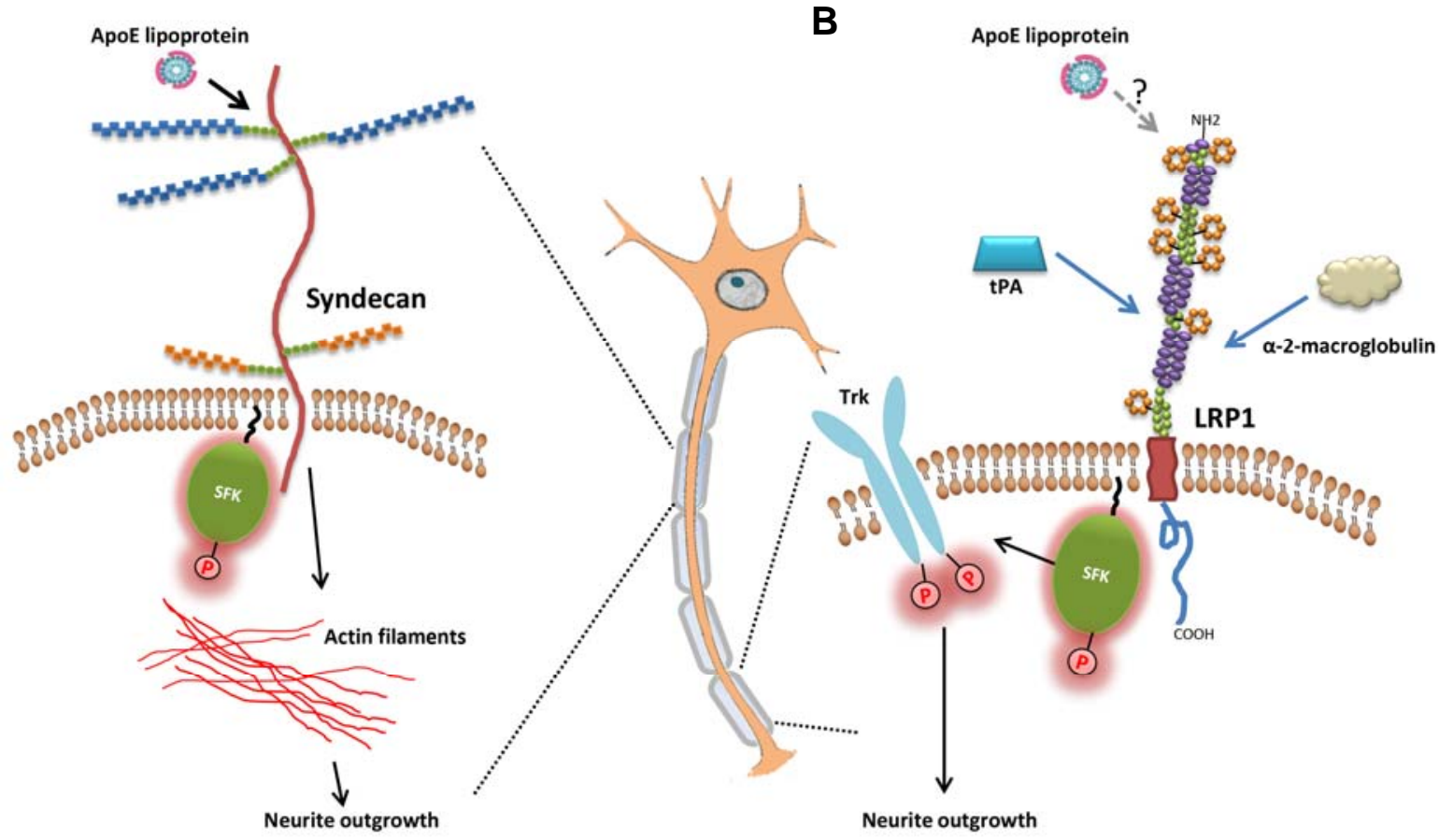

Fig. 1. Signal transduction pathways to regulate neurite outgrowth. (A) Syndecan family member proteins may mediate apoE-dependent neurite outgrowth by interacting with actin filament and Src family kinase (SFK). (B) Activation of LRP1, triggered by ligands such as tissuetype plasminogen activator (tPA) or $\alpha$-2-macroglobulin, activates SFK and TrK receptor, leading to neurite outgrowth.

rin-binding growth-associated molecule (HB-GAM) and promotes neurite outgrowth (Kinnunen et al., 1996). Upon HBGAM binding, $\mathrm{N}$-syndecan facilitates neurite outgrowth through a signal transduction system involving tyrosine kinases of the Src family (Kinnunen et al., 1998). In addition, syndecan-2 also induces the maturation of dendritic spines. Deletion of the Cterminal region of syndecan-2 abrogates the effect of syndecan-2 on spine formation (Ethell and Yamaguchi, 1999). Activation of EphB2 receptor tyrosine kinase and the subsequent interaction of syndecan-2 with PDZ domain proteins, such as syntenin and calcium/calmodulin-dependent serine protein kinase, appear to relay the extracellular signals to the intracellular cytoskeleton/signaling complex (Ethell et al., 2001). Interestingly, syndecan-1 is known to bind and internalize apoE-containing lipoprotein particles, independent of LRP1 in certain cell types (Stanford et al., 2009; Wilsie et al., 2006). Presumably, the interaction of apoE with syndecan occurs through electrostatic interactions between positively charged helix 4 domains of apoE and negatively charged sulfate groups in syndecan HSPG (Libeu et al., 2001). Binding of apoE to syndecan may induce conformational changes in syndecan, leading to recruitment of kinases, PDZ-domain proteins or cytoskeletal proteins. The recruitment of cytoplasmic proteins in turn may trigger a signal cascade that regulates actin assembly at the neurites (Fig. 1A).

\section{Regulation of actin dynamics by LRP8/ApoER2}

Dendritic spines are small protrusions along the dendrite. They are the primary sites of excitatory input on most neurons. Dendritic spine dysfunction and degeneration are thought to be one of the earliest pathogenic events in $A D$ and correlate well with cognitive deficits in $A D$ patients (Selkoe, 2002). Long-term changes in synaptic activity are associated with alterations in spine number, size, and shape. Based on their shapes, spines are classified as thin, stubby, or mushroom spines. Mushroom spines are considered as relatively more stable connections, while thin spines are dynamic and can respond to synaptic activity (Bourne and Harris, 2008). Synaptic enhancement leads to an enlargement of thin spines into mature mushroom spines. Spines with large heads are generally stable and express large numbers of AMPARs, and contribute to strong synaptic connections. In contrast, spines with smaller heads are less stable and represent weak synaptic connections.

Dendritic spine morphogenesis is dynamically regulated primarily by the polymerization and depolymerization of actin filaments within spines. Dynamic rearrangements of actin are regulated by Rho-like small GTPases, Rho-guanine-nucleotide exchange factors (GEFs) and Rho-GTPase activating proteins (GAPs) (Cingolani and Goda, 2008; Penzes and Jones, 2008). For example, stimulation of NMDA receptors during the LTP induction activates Rho GTPases signaling pathway that regulate myosin II motors (Rex et al., 2010). The destabilization of the actin cytoskeleton by myosin II motor allows the synapse to be rebuilt in order to store new information.

Currently, there is no strong evidence that directly links apoE with the modulation of actin dynamics. However, one study demonstrated that activation of apoE receptor family member, LRP8/ApoER2, inhibits the function of n-cofilin and this subsequently leads to stabilization of actin filaments (Chai et al., 2009) (Fig. 2). Non-muscle cofilin (N-cofilin) is found in the neurons and functions as an actin-depolymerizing protein. Modulation of cofilin activity has been directly linked with alteration in dendritic spine morphogenesis, synaptic transmission and plasticity (Kramar et al., 2009; Shankar et al., 2007). Binding of 


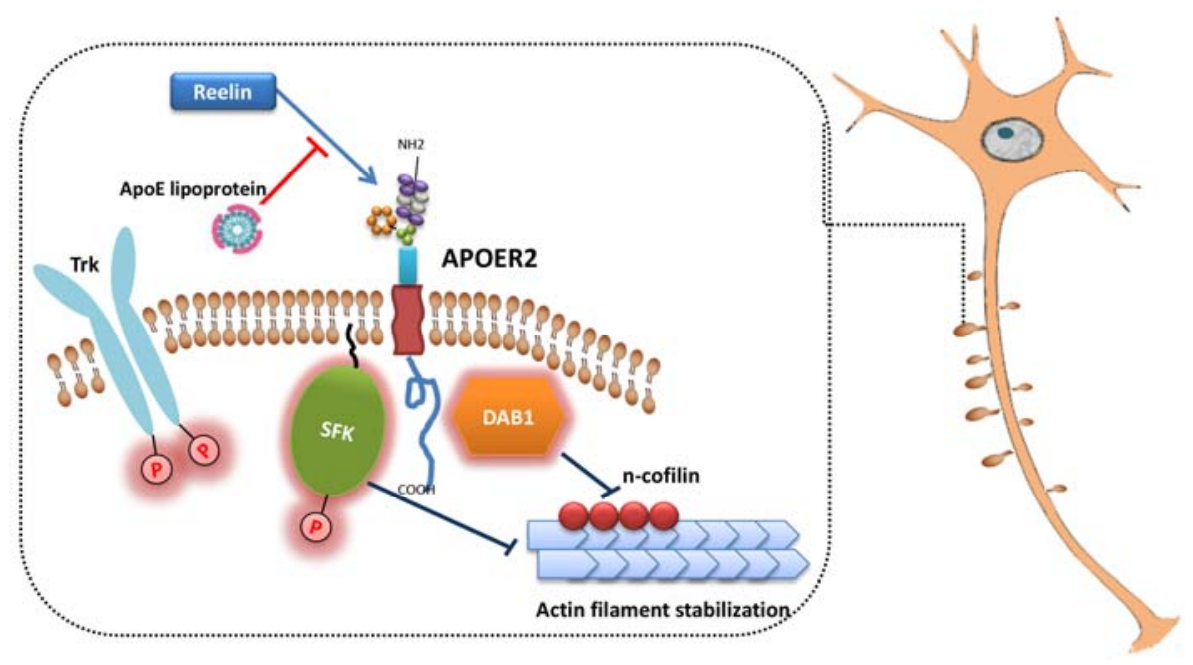

Fig. 2. Role of ApoER2 in dendritic spine morphogenesis. Binding of reelin to ApoER2 induces activation of Diabled-1 and SFK. This subsequently inhibits function of n-cofilin, which leads to filament stabilization. reelin to ApoER2 induces activation of cytosolic adapter protein Disabled-1 (Dab1) and Src family kinases (Fig. 2). Through a series of phosphorylation events, $n$-cofilin becomes inactivated and F-actin cannot be depolymerized in the leading processes of migrating neurons. Stabilization of the actin cytoskeleton by the reelin-ApoER2 signaling pathway might occur at the dendritic spine as well. If so, modulation of actin dynamics at spine will directly affect dendritic spine morphogenesis. Interestingly, apoE is known to interfere with reelin binding to ApoER2 (D'Arcangelo et al., 1999). It is tempting to speculate that apoE may mediate its effect on dendritic spine morphogenesis by indirectly affecting reelin signaling (Niu et al., 2008). However, it is unknown whether cofilin and other small GTPase actin regulators directly mediate differential effects of apoE isoforms on spine growth and elimination via apoE receptors. Alternative mechanisms include the differential effect of apoE isoform on glutamate receptor and apoER2 recycling (Chen et al., 2010). Further in vivo study is needed to determine the direct relevance of these findings on $A D$ pathogenesis.

\section{New emerging role of microtubules in dendritic spine morphogenesis}

It has been generally believed that microtubules are stable and they are distributed only along the dendritic shaft but not in dendritic spines. Therefore, most studies have investigated the dominant roles of actin in dendritic spine morphogenesis and have ignored the potential function of microtubules in dendritic spine. However, emerging data suggests that neuronal microtubules are dynamic and can transiently move from the dendritic shaft to dendritic spines (Gu et al., 2008; Hu et al., 2008). Neuronal activity-dependent transient translocation of microtubules into dendritic spines may be mechanistically linked with the formation of spine head protrusions and rapid spine dynamics (Jaworski et al., 2009). The direct link between microtubule dynamics and actin dynamics warrant further investigation.

Given the fact that tau, the major component of neurofibrillary tangle, is a microtubule stabilizing protein, there have been several studies aimed to investigate the functional link among apoE, tau, and microtubules. The effect of apoE on microtubule organization may be mediated by alteration in microtubuleassociated protein tau. Interestingly, apoE3 binds avidly to tau through the direct interaction between the $\mathrm{N}$-terminal domain of apoE and the microtubule-binding repeat regions of tau, whereas apoE4 does not interact strongly with tau (Strittmatter et al., 1994). However, there is no strong evidence demonstrating apoE's localization to the neuronal cytosol under normal physiological conditions. Limited data suggest that a particular fragment of apoE (1-272 amino acids) can translocate to cytosol and interacts with cytoskeletal proteins (Chang et al., 2005). The physiological relevance of the interaction between apoE fragment and tau warrants further mechanistic studies. However, apoE could affect tau and microtubule by indirectly modulating the signal transduction pathways that regulate tau kinases' activity. For example, the addition of apoE2 caused the strong decrease in phosphorylation of GSK $3 \beta$ and tau, apoE4 the least (Hoe et al., 2006). In addition, RAP treatment abolished the effect of apoE on tau phosphorylation. This finding strongly suggests that the alteration of tau phosphorylation by apoE is mediated by its extracellular interactions with apoE receptors. Although in vitro studies have provided some insights, in vivo studies providing more definitive mechanisms behind the apoE isoform-dependent effects on tau are still lacking. If there is a causal relationship between apoE and tau, it will be critical to understand whether this is due to a direct or indirect interaction.

\section{CONCLUSION}

Although there have been numerous reports demonstrating differential roles of apoE isoforms in various aspects of $A D$ pathogenesis, the underlying mechanism for the increased risk of $A D$ by apoE4 is unclear yet. Our studies suggest that the main effect of apoE on risk for $A D$ is via its effect on $A \beta$ clearance and aggregation (Castellano et al., 2011; Kim et al., 2009b; 2011; 2012a; Liao et al., 2014). However, apoE modulates not only $A \beta$ clearance but also other neuropathological changes observed in $A D$, such as cerebral energy metabolism, neuroinflammation, neurovascular function, neurogenesis, and synaptic plasticity. Given the large overlap between $A \beta-$ and ApoE-mediated pathologic effects, it is difficult to dissect out the exact pathological mechanism mediated by ApoE4 from the purely $A \beta$-mediated effects in human AD cases. Although the presence of $A P O E \varepsilon 4$ allele does not necessarily cause $A D$, apoE may cooperate with $A \beta$ to accelerate $A D$ development and progression in an isoform-dependent manner. With a series of failures in $A \beta$-targeting clinical trials, development of alternative therapeutics for $A D$ is urgently needed. In this re- 
gard, targeting apoE may be an attractive therapeutic strategy for $A D$, either by targeting apoE alone or targeting apoE and $A \beta$ together.

As overviewed in this review, apoE regulates synaptic function in an isoform-dependent manner. In general, apoE4 is associated with detrimental effects on synaptic plasticity, compared with other isoforms. However, there are a significant amount of conflicting findings in isoform-dependent roles of apoE in synaptic plasticity. We cannot exclude the possibility that the absence of more neuroprotective (or less neurotoxic) apoE2 and apoE3, rather than the presence of more neurotoxic apoE4, increases the risk for AD. Clarifying conflicting findings and understanding whether the apoE4-mediated effect on synapse and cognition is due to a gain of detrimental functions or loss of protective functions will have critical implications for the development of apoE-targeting treatments. Therefore, further studies are warranted to determine how apoE affects synaptic plasticity and other AD pathologies.

\section{ACKNOWLEDGMENTS}

This work was supported by grants from BrightFocus Foundation, Alzheimer's Association, NIH AG016574, and GHR Foundation to JK.

\section{REFERENCES}

Bales, K.R., Verina, T., Dodel, R.C., Du, Y., Altstiel, L., Bender, M., Hyslop, P., Johnstone, E.M., Little, S.P., Cummins, D.J., et al. (1997). Lack of apolipoprotein E dramatically reduces amyloid beta-peptide deposition. Nat. Genet. 17, 263-264.

Basak, J.M., and Kim, J. (2010). Differential effects of ApoE isoforms on dendritic spines in vivo: linking an Alzheimer's disease risk factor with synaptic alterations. J. Neurosci. 30, 4526-4527.

Bien-Ly, N., Gillespie, A.K., Walker, D., Yoon, S.Y., and Huang, Y. (2012). Reducing human apolipoprotein E levels attenuates age-dependent $A \beta$ accumulation in mutant human amyloid precursor protein transgenic mice. J. Neurosci. 32, 4803-4811.

Bour, A., Grootendorst, J., Vogel, E., Kelche, C., Dodart, J.C., Bales, K., Moreau, P.H., Sullivan, P.M., and Mathis, C. (2008). Middleaged human apoE4 targeted-replacement mice show retention deficits on a wide range of spatial memory tasks. Behav. Brain Res. 193, 174-182.

Bourne, J.N., and Harris, K.M. (2008). Balancing structure and function at hippocampal dendritic spines. Annu. Rev. Neurosci. 31, 47-67.

Buttini, M., Orth, M., Bellosta, S., Akeefe, H., Pitas, R.E., WyssCoray, T., Mucke, L., and Mahley, R.W. (1999). Expression of human apolipoprotein E3 or E4 in the brains of Apoe-/- mice: isoform-specific effects on neurodegeneration. J. Neurosci. 19, 4867-4880.

Cambon, K., Davies, H.A., and Stewart, M.G. (2000). Synaptic loss is accompanied by an increase in synaptic area in the dentate gyrus of aged human apolipoprotein E4 transgenic mice. Neuroscience 97, 685-692.

Castellano, J.M., Kim, J., Stewart, F.R., Jiang, H., DeMattos, R.B., Patterson, B.W., Fagan, A.M., Morris, J.C., Mawuenyega, K.G., Cruchaga, C., et al. (2011). Human apoE isoforms differentially regulate brain amyloid- $\beta$ peptide clearance. Sci. Transl. Med. 3, 89 ra57.

Chai, X., Forster, E., Zhao, S., Bock, H.H., and Frotscher, M. (2009). Reelin stabilizes the actin cytoskeleton of neuronal processes by inducing $\mathrm{n}$-cofilin phosphorylation at serine3. J. Neurosci. 29, 288-299.

Chang, S., ran Ma, T., Miranda, R.D., Balestra, M.E., Mahley, R.W. and Huang, Y. (2005). Lipid- and receptor-binding regions of apolipoprotein E4 fragments act in concert to cause mitochondrial dysfunction and neurotoxicity. Proc. Natl. Acad. Sci. USA 102, 18694-18699.

Chen, Y., Durakoglugil, M.S., Xian, X. and Herz, J. (2010). ApoE4 reduces glutamate receptor function and synaptic plasticity by selectively impairing ApoE receptor recycling. Proc. Natl. Acad.
Sci. USA 107, 12011-12016.

Cingolani, L.A., and Goda, Y. (2008). Actin in action: the interplay between the actin cytoskeleton and synaptic efficacy. Nat. Rev. Neurosci. 9, 344-356.

Corder, E.H., Saunders, A.M., Strittmatter, W.J., Schmechel, D.E., Gaskell, P.C., Small, G.W., Roses, A.D., Haines, J.L., and Pericak-Vance, M.A. (1993). Gene dose of apolipoprotein E type 4 allele and the risk of Alzheimer's disease in late onset families. Science 261, 921-923

Cramer, P.E., Cirrito, J.R., Wesson, D.W., Lee, C.Y., Karlo, J.C., Zinn, A.E., Casali, B.T., Restivo, J.L., Goebel, W.D., James, M.J., et al. (2012). ApoE-directed therapeutics rapidly clear betaamyloid and reverse deficits in AD mouse models. Science 335 1503-1506.

D'Arcangelo, G., Homayouni, R., Keshvara, L., Rice, D.S., Sheldon, M., and Curran, T. (1999). Reelin is a ligand for lipoprotein receptors. Neuron 24, 471-479.

DeMattos, R.B., Curtiss, L.K., and Williams, D.L. (1998). A minimally lipidated form of cell-derived apolipoprotein $E$ exhibits isoform-specific stimulation of neurite outgrowth in the absence of exogenous lipids or lipoproteins. J. Biol. Chem. 273, 42064212.

Dietschy, J.M., and Turley, S.D. (2004). Thematic review series: brain Lipids. Cholesterol metabolism in the central nervous system during early development and in the mature animal. J. Lipid Res. 45, 1375-1397.

Dumanis, S.B., Tesoriero, J.A., Babus, L.W., Nguyen, M.T., Trotter J.H., Ladu, M.J., Weeber, E.J., Turner, R.S., Xu, B., Rebeck, G.W., et al. (2009). ApoE4 decreases spine density and dendritic complexity in cortical neurons in vivo. J. Neurosci. 29, 15317-15322.

Ethell, I.M., and Yamaguchi, Y. (1999). Cell surface heparan sulfate proteoglycan syndecan-2 induces the maturation of dendritic spines in rat hippocampal neurons. J. Cell Biol. 144, 575-586.

Ethell, I.M., Irie, F., Kalo, M.S., Couchman, J.R., Pasquale, E.B., and Yamaguchi, Y. (2001). EphB/syndecan-2 signaling in dendritic spine morphogenesis. Neuron 31, 1001-1013.

Fagan, A.M., Bu, G., Sun, Y., Daugherty, A., and Holtzman, D.M. (1996). Apolipoprotein E-containing high density lipoprotein promotes neurite outgrowth and is a ligand for the low density lipoprotein receptor-related protein. J. Biol. Chem. 271, 3012130125.

Farrer, L.A., Cupples, L.A., Haines, J.L., Hyman, B., Kukull, W.A., Mayeux, R., Myers, R.H., Pericak-Vance, M.A., Risch, N., and van Duijn, C.M. (1997). Effects of age, sex, and ethnicity on the association between apolipoprotein $\mathrm{E}$ genotype and Alzheimer disease. A meta-analysis. APOE and Alzheimer Disease Meta Analysis Consortium. JAMA 278, 1349-1356.

Golde, T.E., Petrucelli, L., and Lewis, J. (2010). Targeting Abeta and tau in Alzheimer's disease, an early interim report. Exp. Neurol. 223, 252-266.

Gordon, I., Grauer, E., Genis, I., Sehayek, E., and Michaelson, D.M. (1995). Memory deficits and cholinergic impairments in apolipoprotein E-deficient mice. Neurosci. Lett. 199, 1-4

Grootendorst, J., Bour, A., Vogel, E., Kelche, C., Sullivan, P.M., Dodart, J.-C., Bales, K., and Mathis, C. (2005) Human apoE targeted replacement mouse lines: h-apoE4 and h-apoE3 mice differ on spatial memory performance and avoidance behavior. Behav. Brain Res. 159, 1-14.

Gu, J., Firestein, B.L., and Zheng, J.Q. (2008). Microtubules in dendritic spine development. J. Neurosci. 28, 12120-12124.

Haass, C., and Selkoe, D.J. (2007). Soluble protein oligomers in neurodegeneration: lessons from the Alzheimer's amyloid betapeptide. Nat. Rev. Mol. Cell Biol. 8, 101-112.

Hartman, R.E., Wozniak, D.F., Nardi, A., Olney, J.W., Sartorius, L., and Holtzman, D.M. (2001). Behavioral phenotyping of GFAPApoE3 and -ApoE4 transgenic mice: ApoE4 mice show profound working memory impairments in the absence of Alzheimer's-like neuropathology. Exp. Neurol. 170, 326-344.

Hoe, H.S., Freeman, J., and Rebeck, G.W. (2006). Apolipoprotein E decreases tau kinases and phospho-tau levels in primary neurons. Mol. Neurodegener. 1, 18

Holtzman, D.M., Pitas, R.E., Kilbridge, J., Nathan, B., Mahley, R.W., Bu, G., and Schwartz, A.L. (1995). Low density lipoprotein receptor-related protein mediates apolipoprotein E-dependent neurite outgrowth in a central nervous system-derived neuronal 
cell line. Proc. Natl. Acad. Sci. USA 92, 9480-9484.

Hu, X., Viesselmann, C., Nam, S., Merriam, E., and Dent, E.W. (2008). Activity-dependent dynamic microtubule invasion of dendritic spines. J. Neurosci. 28, 13094-13105.

Hudry, E., Dashkoff, J., Roe, A.D., Takeda, S., Koffie, R.M., Hashimoto, T., Scheel, M., Spires-Jones, T., Arbel-Ornath, M., Betensky, R., et al. (2013). Gene transfer of human apoe isoforms results in differential modulation of amyloid deposition and neurotoxicity in mouse brain. Sci. Transl. Med. 5, 212ra161.

Jaworski, J., Kapitein, L.C., Gouveia, S.M., Dortland, B.R., Wulf, P.S., Grigoriev, I., Camera, P., Spangler, S.A., Di Stefano, P., Demmers, J., et al. (2009). Dynamic microtubules regulate dendritic spine morphology and synaptic plasticity. Neuron 61, 85-100.

Ji, Z.S., Pitas, R.E., and Mahley, R.W. (1998). Differential cellular accumulation/retention of apolipoprotein $\mathrm{E}$ mediated by cell surface heparan sulfate proteoglycans. Apolipoproteins E3 and E2 greater than e4. J. Biol. Chem. 273, 13452-13460.

Ji, Y., Gong, Y., Gan, W., Beach, T., Holtzman, D.M., and Wisniewski, T. (2003). Apolipoprotein E isoform-specific regulation of dendritic spine morphology in apolipoprotein $E$ transgenic mice and Alzheimer's disease patients. Neuro Sci. 122, 305-315.

Jiang, Q., Lee, C.Y., Mandrekar, S., Wilkinson, B., Cramer, P., Zelcer, N., Mann, K., Lamb, B., Willson, T.M., Collins, J.L., et al. (2008). ApoE promotes the proteolytic degradation of Abeta. Neuron 58, 681-693.

Kim, J., Onstead, L., Randle, S., Price, R., Smithson, L., Zwizinski, C., Dickson, D.W., Golde, T., and McGowan, E. (2007) Abeta40 inhibits amyloid deposition in vivo. J. Neurosci. 27, 627633

Kim, J., Basak, J.M., and Holtzman, D.M. (2009a). The role of apolipoprotein E in Alzheimer's disease. Neuron 63, 287-303.

Kim, J., Castellano, J.M., Jiang, H., Basak, J.M., Parsadanian, M., Pham, V., Mason, S.M., Paul, S.M., and Holtzman, D.M. (2009b). Overexpression of low-density lipoprotein receptor in the brain markedly inhibits amyloid deposition and increases extracellular A[beta] clearance. Neuron 64, 632-644.

Kim, J., Jiang, H., Park, S., Eltorai, A., Stewart, F., Yoon, H., Basak, J.M., Finn, M.B., and Holtzman, D.M. (2011). Haploinsufficiency of human APOE reduces amyloid deposition in a mouse model of amyloid-beta amyloidosis. J. Neurosci. 31, 18007-18012.

Kim, J., Eltorai, A.E., Jiang, H., Liao, F., Verghese, P.B., Kim, J., Stewart, F.R., Basak, J.M., and Holtzman, D.M. (2012a). AntiapoE immunotherapy inhibits amyloid accumulation in a transgenic mouse model of Abeta amyloidosis. J. Exp. Med. 209, 2149-2156

Kim, J, Yoon, H., Ramírez, C. Lee, $\mathrm{S}$, Hoe, $\mathrm{H}$, FernándezHernando, C., and Kim, J. (2012b). miR-106b impairs cholesterol efflux and increases $A \beta$ levels by repressing ABCA1 expression. Exp. Neurol. 235, 476-483.

Kinnunen, T., Raulo, E., Nolo, R., Maccarana, M., Lindahl, U., and Rauvala, H. (1996). Neurite outgrowth in brain neurons induced by heparin-binding growth-associated molecule (HB-GAM) depends on the specific interaction of HB-GAM with heparan sulfate at the cell surface. J. Biol. Chem. 271, 2243-2248.

Kinnunen, T., Kaksonen, M., Saarinen, J., Kalkkinen, N., Peng, H.B., and Rauvala, H. (1998). Cortactin-Src kinase signaling pathway is involved in $\mathrm{N}$-syndecan-dependent neurite outgrowth. J. Biol. Chem. 273, 10702-10708.

Kitamura, H.W., Hamanaka, H., Watanabe, M., Wada, K. Yamazaki, C., Fujita, S.C., Manabe, T., and Nukina, N. (2004). Age-dependent enhancement of hippocampal long-term potentiation in knock-in mice expressing human apolipoprotein E4 instead of mouse apolipoprotein E. Neurosci. Lett. 369, 173178

Kornecook, T.J., McKinney, A.P., Ferguson, M.T., and Dodart, J.C. (2010). Isoform-specific effects of apolipoprotein E on cognitive performance in targeted-replacement mice overexpressing human APP. Genes Brain Behav. 9, 182-192.

Kowal, R.C., Herz, J., Weisgraber, K.H., Mahley, R.W., Brown, M.S., and Goldstein, J.L. (1990). Opposing effects of apolipoproteins $\mathrm{E}$ and $\mathrm{C}$ on lipoprotein binding to low density lipoprotein receptor-related protein. J. Biol. Chem. 265, 10771-10779.

Kramar, E.A., Chen, L.Y., Brandon, N.J., Rex, C.S., Liu, F., Gall, C.M., and Lynch, G. (2009). Cytoskeletal changes underlie estrogen's acute effects on synaptic transmission and plasticity. J. Neurosci. 29, 12982-12993.

Kuszczyk, M.A., Sanchez, S., Pankiewicz, J., Kim, J., Duszczyk, M. Guridi, M., Asuni, A.A., Sullivan, P.M., Holtzman, D.M., and Sadowski, M.J. (2013). Blocking the interaction between apolipoprotein $\mathrm{E}$ and Abeta reduces intraneuronal accumulation of Abeta and inhibits synaptic degeneration. Am. J. Pathol. 182, 1750-1768.

Lane-Donovan, C., Philips, Gary T., and Herz, J. (2014). More than cholesterol transporters: lipoprotein receptors in CNS function and neurodegeneration. Neuron 83, 771-787.

Lanz, T.A., Carter, D.B., and Merchant, K.M. (2003). Dendritic spine loss in the hippocampus of young PDAPP and Tg2576 mice and its prevention by the ApoE2 genotype. Neurobiol. Dis. 13 246-253.

Liao, F., Hori, Y., Hudry, E., Bauer, A.Q., Jiang, H., Mahan, T.E., Lefton, K.B., Zhang, T.J., Dearborn, J.T., Kim, J., et al. (2014) Anti-ApoE antibody given after plaque onset decreases Abeta accumulation and improves brain function in a mouse model of Abeta amyloidosis. J. Neurosci. 34, 7281-7292.

Libeu, C.P., Lund-Katz, S., Phillips, M.C., Wehrli, S., Hernaiz, M.J., Capila, I., Linhardt, R.J., Raffai, R.L., Newhouse, Y.M., Zhou, F., et al. (2001). New insights into the heparan sulfate proteoglycanbinding activity of apolipoprotein E. J. Biol. Chem. 276, 3913839144.

Mahley, R.W., and Huang, Y. (2012). Apolipoprotein e sets the stage: response to injury triggers neuropathology. Neuron 76 871-885.

Mak, A.C., Pullinger, C.R., Tang, L.F., Wong, J.S., Deo, R.C. Schwarz, J.M., Gugliucci, A., Movsesyan, I., Ishida, B.Y., Chu, C., et al. (2014). Effects of the absence of apolipoprotein $E$ on lipoproteins, neurocognitive function, and retinal runction. JAMA Neurol. (in press).

Mann, K.M., Thorngate, F.E., Katoh-Fukui, Y., Hamanaka, H. Williams, D.L., Fujita, S., and Lamb, B.T. (2004). Independent effects of APOE on cholesterol metabolism and brain Abeta levels in an Alzheimer disease mouse model. Hum. Mol. Genet. 13, 1959-1968.

Masliah, E., Samuel, W., Veinbergs, I., Mallory, M., Mante, M., and Saitoh, T. (1997). Neurodegeneration and cognitive impairment in apoE-deficient mice is ameliorated by infusion of recombinant apoE. Brain Res. 751, 307-314

McGowan, E., Pickford, F., Kim, J., Onstead, L., Eriksen, J., Yu, C., Skipper, L., Murphy, M.P., Beard, J., Das, P., et al. (2005) Abeta42 is essential for parenchymal and vascular amyloid deposition in mice. Neuron 47, 191-199.

Minami, S.S., Cordova, A., Cirrito, J.R., Tesoriero, J.A., Babus, L.W., Davis, G.C., Dakshanamurthy, S., Turner, R.S., Pak, D.T., Rebeck, G.W., et al. (2010). ApoE mimetic peptide decreases Abeta production in vitro and in vivo. Mol. Neurodegener. 5, 16.

Namba, Y., Tomonaga, M., Kawasaki, H., Otomo, E., and Ikeda, K. (1991). Apolipoprotein E immunoreactivity in cerebral amyloid deposits and neurofibrillary tangles in Alzheimer's disease and kuru plaque amyloid in Creutzfeldt-Jakob disease. Brain Res. 541, 163-166.

Narita, M., Bu, G., Holtzman, D.M., and Schwartz, A.L. (1997). The low-density lipoprotein receptor-related protein, a multifunctional apolipoprotein E receptor, modulates hippocampal neurite development. J. Neurochem. 68, 587-595.

Nathan, B.P., Bellosta, S., Sanan, D.A., Weisgraber, K.H., Mahley, R.W. and Pitas, R.E. (1994). Differential effects of apolipoproteins E3 and E4 on neuronal growth in vitro. Science 264, 850-852.

Nathan, B.P., Jiang, Y., Wong, G.K., Shen, F., Brewer, G.J., and Struble, R.G. (2002). Apolipoprotein E4 inhibits, and apolipoprotein E3 promotes neurite outgrowth in cultured adult mouse cortical neurons through the low-density lipoprotein receptor-related protein. Brain Res. 928, 96-105.

Nichol, K., Deeny, S.P., Seif, J., Camaclang, K., and Cotman, C.W (2009). Exercise improves cognition and hippocampal plasticity in APOE epsilon4 mice. Alzheimers Dement 5, 287-294.

Niu, S., Yabut, O., and D'Arcangelo, G. (2008). The reelin signaling pathway promotes dendritic spine development in hippocampal neurons. J. Neurosci. 28, 10339-10348.

Osherovich, L. (2009). The APOE4 conundrum. SciBX 2, 1-3.

Pankiewicz, J.E., Guridi, M., Kim, J., Asuni, A.A., Sanchez, S., 
Sullivan, P.M., Holtzman, D.M., and Sadowski, M.J. (2014). Blocking the apoE/Abeta interaction ameliorates Abeta-related pathology in APOE2 and 4 targeted replacement Alzheimer model mice. Acta Neuropathol. Commun. 2, 75.

Penzes, P., and Jones, K.A. (2008). Dendritic spine dynamics--a key role for kalirin-7. Trends Neurosci. 31, 419-427.

Puttfarcken, P.S., Manelli, A.M., Falduto, M.T., Getz, G.S., and LaDu, M.J. (1997). Effect of apolipoprotein $E$ on neurite outgrowth and beta-amyloid-induced toxicity in developing rat primary hippocampal cultures. J. Neurochem. 68, 760-769.

Raber, J., Wong, D., Buttini, M., Orth, M., Bellosta, S., Pitas, R.E., Mahley, R.W., and Mucke, L. (1998). Isoform-specific effects of human apolipoprotein $\mathrm{E}$ on brain function revealed in ApoE knockout mice: increased susceptibility of females. Proc. Natl. Acad. Sci. USA 95, 10914-10919.

Raber, J., Wong, D., Yu, G.Q., Buttini, M., Mahley, R.W., Pitas, R.E. and Mucke, L. (2000). Apolipoprotein E and cognitive performance. Nature 404, 352-354.

Ramaswamy, G., Xu, Q., Huang, Y., and Weisgraber, K.H. (2005). Effect of domain interaction on apolipoprotein $E$ levels in mouse brain. J. Neurosci. 25, 10658-10663.

Rex, C.S., Gavin, C.F., Rubio, M.D., Kramar, E.A., Chen, L.Y., Jia, Y., Huganir, R.L., Muzyczka, N., Gall, C.M., and Miller, C.A (2010). Myosin Ilb regulates actin dynamics during synaptic plasticity and memory formation. Neuron $67,603-617$.

Riddell, D.R., Zhou, H., Atchison, K., Warwick, H.K., Atkinson, P.J., Jefferson, J., Xu, L., Aschmies, S., Kirksey, Y., Hu, Y., et al. (2008). Impact of Apolipoprotein E (ApoE) polymorphism on brain ApoE levels. J. Neurosci. 28, 11445-11453.

Ruiz, J., Kouiavskaia, D., Migliorini, M., Robinson, S., Saenko, E.L., Gorlatova, N., Li, D., Lawrence, D., Hyman, B.T., Weisgraber, K.H., et al. (2005). The apoE isoform binding properties of the VLDL receptor reveal marked differences from LRP and the LDL receptor. J. Lipid Res. 46, 1721-1731.

Sadowski, M., Pankiewicz, J., Scholtzova, H., Ripellino, J.A., Li, Y., Schmidt, S.D., Mathews, P.M., Fryer, J.D., Holtzman, D.M., Sigurdsson, E.M., et al. (2004). A synthetic peptide blocking the Apolipoprotein $\mathrm{E} /\{$ beta\}-amyloid binding mitigates \{beta\}-amyloid toxicity and fibril formation in vitro and reduces \{beta\}-amyloid plaques in transgenic mice. Am. J. Pathol. 165, 937-948.

Sadowski, M.J., Pankiewicz, J., Scholtzova, H., Mehta, P.D., Prelli, F., Quartermain, D., and Wisniewski, T. (2006). Blocking the apolipoprotein E/amyloid-\{beta\} interaction as a potential therapeutic approach for Alzheimer's disease. Proc. Natl. Acad. Sci. USA 103, 18787-18792.

Selkoe, D.J. (2002). Alzheimer's disease is a synaptic failure. Science 298, 789-791.

Shankar, G.M., Bloodgood, B.L., Townsend, M., Walsh, D.M., Selkoe, D.J., and Sabatini, B.L. (2007). Natural oligomers of the Alzheimer amyloid-beta protein induce reversible synapse loss by modulating an NMDA-type glutamate receptor-dependent signaling pathway. J. Neurosci. 27, 2866-2875.

Shi, Y., Mantuano, E., Inoue, G., Campana, W.M., and Gonias, S.L. (2009). Ligand binding to LRP1 transactivates Trk receptors by a Src family kinase-dependent pathway. Sci. Signal. 2, ra18.

Siegel, J.A., Haley, G.E., and Raber, J. (2012). Apolipoprotein E isoform-dependent effects on anxiety and cognition in female TR mice. Neurobiol. Aging 33, 345-358.

Stanford, K.I., Bishop, J.R., Foley, E.M., Gonzales, J.C., Niesman, I.R., Witztum, J.L., and Esko, J.D. (2009). Syndecan-1 is the primary heparan sulfate proteoglycan mediating hepatic clearance of triglyceride-rich lipoproteins in mice. J. Clin. Invest.
$119,3236-3245$

Strittmatter, W.J., Saunders, A.M., Goedert, M., Weisgraber, K.H., Dong, L.M., Jakes, R., Huang, D.Y., Pericak-Vance, M. Schmechel, D., and Roses, A.D. (1994). Isoform-specific interactions of apolipoprotein E with microtubule-associated protein tau: implications for Alzheimer disease. Proc. Natl. Acad Sci. USA 91, 11183-11186

Sun, Y., Wu, S., Bu, G., Onifade, M.K., Patel, S.N., LaDu, M.J., Fagan, A.M., and Holtzman, D.M. (1998). Glial fibrillary acidic protein-apolipoprotein $\mathrm{E}(\mathrm{apoE})$ transgenic mice: astrocytespecific expression and differing biological effects of astrocytesecreted apoE3 and apoE4 lipoproteins. J. Neurosci. 18, 32613272.

Terry, R.D., Masliah, E., Salmon, D.P., Butters, N., DeTeresa, R., Hill, R., Hansen, L.A. and Katzman, R. (1991). Physical basis of cognitive alterations in Alzheimer's disease: synapse loss is the major correlate of cognitive impairment. Ann. Neurol. 30, 572580

Teter, B., Xu, P.T., Gilbert, J.R., Roses, A.D., Galasko, D., and Cole G.M. (1999). Human apolipoprotein $E$ isoform-specific differences in neuronal sprouting in organotypic hippocampal culture. J. Neurochem. 73, 2613-2616

Teter, B., Xu, P.T., Gilbert, J.R., Roses, A.D., Galasko, D., and Cole G.M. (2002). Defective neuronal sprouting by human apolipoprotein E4 is a gain-of-negative function. J. Neurosci. Res. 68, 331-336.

Trommer, B.L., Shah, C., Yun, S.H., Gamkrelidze, G., Pasternak E.S., Ye, G.L., Sotak, M., Sullivan, P.M., Pasternak, J.F., and LaDu, M.J. (2004). ApoE isoform affects LTP in human targeted replacement mice. Neuroreport 15, 2655-2658.

Trommer, B.L., Shah, C., Yun, S.H., Gamkrelidze, G., Pasternak, E.S., Stine, W.B., Manelli, A., Sullivan, P., Pasternak, J.F., and LaDu, M.J. (2005). ApoE isoform-specific effects on LTP blockade by oligomeric amyloid-beta1-42. Neurobiol. Dis. 18, 75-82.

Veinbergs, I., Mallory, M., Mante, M., Rockenstein, E., Gilbert, J.R., and Masliah, E. (1999). Differential neurotrophic effects of apolipoprotein E in aged transgenic mice. Neurosci. Lett. 265, 218-222.

Vitek, M.P., Brown, C.M., and Colton, C.A. (2007). APOE genotypespecific differences in the innate immune response. Neurobiol. Aging 30, 1350-1360.

Wahrle, S.E., Jiang, H., Parsadanian, M., Kim, J., Li, A., Knoten, A. Jain, S., Hirsch-Reinshagen, V., Wellington, C.L., Bales, K.R., et al. (2008). Overexpression of ABCA1 reduces amyloid deposition in the PDAPP mouse model of Alzheimer disease. J. Clin. Invest. 118, 671-682

Walsh, D.M., and Selkoe, D.J. (2004). Deciphering the molecular basis of memory failure in Alzheimer's disease. Neuron 44, 181193.

Wang, C., Wilson, W.A., Moore, S.D., Mace, B.E., Maeda, N. Schmechel, D.E., and Sullivan, P.M. (2005). Human apoE4targeted replacement mice display synaptic deficits in the absence of neuropathology. Neurobiol. Dis. 18, 390-398.

White, F., Nicoll, J.A., Roses, A.D., and Horsburgh, K. (2001). Impaired neuronal plasticity in transgenic mice expressing human apolipoprotein E4 compared to E3 in a model of entorhinal cortex lesion. Neurobiol. Dis. 8, 611-625.

Wilsie, L.C., Gonzales, A.M., and Orlando, R.A. (2006). Syndecan1 mediates internalization of apoE-VLDL through a low density lipoprotein receptor-related protein (LRP)-independent, nonclathrin-mediated pathway. Lipids Health Dis. 5, 23. 